\title{
IDENTIFICATION OF EARTHQUAKE AFTERSHOCK AND SWARM SEQUENCES IN THE BAIKAL RIFT ZONE
}

\author{
N. A. Radziminovich ${ }^{1}$, M. G. Ochkovskaya ${ }^{2}$ \\ ${ }^{1}$ Institute of the Earth's Crust, SB RAS, Irkutsk, Russia \\ ${ }^{2}$ Baikal Division of Geophysical Survey, SB RAS, Irkutsk, Russia
}

\begin{abstract}
The catalog of earthquakes ( $\left.K_{R} \geq 6.6\right)$ which occurred in the Baikal rift zone (BRZ) was declastered, and the results are presented in the article. Aftershocks of seismic events $\left(K_{R} \geq 12.5\right)$ were determined by the software developed by V.B. Smirnov (Lomonosov Moscow State University) with application of the algorithm co-authored by G.M. Molchan and O.E. Dmitrieva. To ensure proper control of the software application, aftershocks were also selected manually. The results of declustering show that aftershocks of the earthquakes $\left(K_{R} \geq 12.5\right)$ account for about 25 per cent of all seismic events in the regional catalog. Aftershocks accompanied 90 per cent of all the earthquakes considered as main shocks. Besides, earthquake swarms, including events with $K_{R} \geq 11$, were identified. The results of this study show that, in the BRZ, the swarms and strong events with aftershocks are not spatially separated, and this conclusion differs from the views of the previous studies that reviewed data from a shorter observation period. Moreover, it is noted that the swarms may consist of several main shocks accompanied by aftershocks. The data accumulated over the last fifty years of instrumental observations support the conclusion made earlier that the swarms in BRZ occur mainly in the north-eastward direction from Lake Baikal and also confirm the trend of a small number of aftershocks accompanying earthquakes in the south-western part of the Baikal rift zone.
\end{abstract}

Key words: Baikal rift zone, seismicity, aftershocks, earthquake swarms, catalogue declustering.

Recommended by V.S. Imayev

Citation: Radziminovich N.A., Ochkovskaya M.G. 2013. Identification of earthquake aftershock and swarm sequences in the Baikal rift zone. Geodynamics \& Tectonophysics 4 (2), 169-186. doi:10.5800/GT-2013-4-2-0096.

\section{ВЫДЕЛЕНИЕ АФТЕРШОКОВЫХ И РОЕВЫХ ПОСЛЕДОВАТЕЛЬНОСТЕЙ ЗЕМЛЕТРЯСЕНИЙ БАЙКАЛЬСКОЙ РИФТОВОЙ ЗОНЫ}

\author{
Н. А. Радзиминович ${ }^{1}$, М. Г. Очковская ${ }^{2}$ \\ ${ }^{1}$ Институт земной коры СО РАН, Иркутск, Россия \\ ${ }^{2}$ Байкальский филиал Геофизической службы СО РАН, Иркутск, Россия
}

Аннотация: В статье приведены описание и результаты декластеризации каталога землетрясений Байкальской рифтовой зоны (с $\left.K_{\mathrm{p}} \geq 6.6\right)$. Идентификация афтершоков для событий с $\mathrm{K}_{\mathrm{p}} \geq 12.5$ осуществлялась с использованием программы В.Б. Смирнова (МГУ им. М.В. Ломоносова), в которой реализован алгоритм, разработанный Г.М. Молчан и О.Е. Дмитриевой. Для контроля работы программы афтершоки выбирались также вручную. Результаты декластеризации показали, что афтершоки землетрясений с $\mathrm{K}_{\mathrm{p}} \geq 12.5$ составляют примерно 25 \% всех событий в региональном каталоге. Афтершоками сопровождались 90 \% всех землетрясений, рассматриваемых в качестве главных толчков. Были выделены также рои землетрясений, в которых есть события с $K_{\mathrm{p}} \geq 11$. Результаты данной работы показывают, 
что и рои, и сильные толчки с афтершоками в Байкальской рифтовой зоне (БРЗ) пространственно не разобщены, как это считалось в предыдущих работах по данным менышего по длительности периода наблюдений. Более того, отмечается, что рои могут состоять из нескольких главных толчков со своими афтершоками. Материалы наблюдений за пятидесятилетний период инструментальных наблюдений подтверждают сделанные ранее выводы о том, что рои в БР3 происходят в основном к северо-востоку от озера Байкал, а также о тенденции к малому количеству афтершоков у землетрясений юго-западного фланга БРЗ.

Ключевые слова: Байкальская рифтовая зона, сейсмичность, афтершоки, рои землетрясений, декластеризация каталога.

\section{1. ВВЕДЕНИЕ}

Афтершоковые и роевые последовательности землетрясений представляют значительную часть сейсмического процесса и приводят к отклонению от пуассоновского распределения, характерного для «независимых» или фоновых землетрясений [Gardner, Knopoff, 1974]. В то же время для решения многих задач, например при оценке сейсмического риска, изменения скорости сейсмического потока, при разработке алгоритмов прогноза сильных событий, требуется каталог, отвечающий стационарному пуассоновскому процессу и, следовательно, очищенный от группирующихся взаимосвязанных или взаимообусловленных землетрясений, коими и являются форшоки, афтершоки и рои. Наиболее однозначным примером зависимых землетрясений служат афтершоки, поэтому процедура очистки каталогов, или декластеризация, направлена на выделение главного толчка и проверку наличия у него афтершоков. Выделение роев землетрясений представляет собой более сложную задачу, так как входящие в них события являются фактически независимыми друг от друга, хоть их возникновение и обусловлено одним процессом.

Следует отметить, что, несмотря на кажущуюся простоту выделения группирующихся событий вследствие их концентрации в пространстве и времени, в большинстве случаев невозможно достоверно отнести индивидуальные толчки к фоновым или афтершокам (роевым событиям), особенно на периферии кластера и на начальных и терминальных стадиях активности. Тем не менее именно расстояние и время между соседними событиями являются основой большинства методов выделения группирующихся землетрясений. Например, такой метод для выделения роев в сейсмологическом каталоге предложен в работе [Waite, 1999]. Для идентификации афтершоков используется также зависимость длительности последовательности и размера эпицентрального поля от магнитуды главного толчка. Такой способ декластеризации, называемый оконным, был использован в работе [Gardner, Knopoff, 1974]. Ярким примером оконного метода служит метод А.Г. Прозорова [Prozorov, 1986]. Другим известным алгоритмом выделения афтершоков является кла- стерный метод. Наибольшую популярность получил метод Резенберга [Reasenberg, 1985], который позволяет выделять не только афтершоки, но и форшоки. Нововведением в данном подходе является использование закона Омори для определения временных рамок последовательности. К методам такого типа принадлежит и алгоритм, разработанный Г.М. Молчан и O.Е. Дмитриевой [Molchan, Dmitrieva, 1991, 1992]. Примером совершенно другого класса методов декластеризации служат стохастические алгоритмы [Zhuang et al., 2002]. В целом, существует большое количество методов и алгоритмов выделения группирующихся событий, однако при использовании любого из них решающее значение имеет полнота и качество каталога.

Байкальская рифтовая зона (БРЗ) характеризуется коровой сейсмичностью с сейсмическим потенциалом, превышающим магнитуду 7 [Khromovskikh et al., 1996]. Практически все сильные землетрясения, как исторические, например Цаганское 1862 г. с $\mathrm{M}=7.5$ [Kondorskaya, Shebalin, 1982], так и зарегистрированные инструментально, сопровождались афтершоками. С развитием региональной сети сейсмологических наблюдений появились также описания роевых последовательностей [Kochetkov et al., 1987; Deverchere et al., 1991]. Однако началом изучения группирующихся землетрясений следует, по-видимому, считать все же 1959 г., когда для регистрации афтершоков Среднебайкальского землетрясения с $\mathrm{M=6.8}$ были выставлены дополнительные временные станции [Solonenko, Treskov, 1960; Misharina, 1961; Golenetskii, 1961; Pshennikov, 1962]. С этого времени накоплен и проанализирован обширный сейсмологический материал [Pshennikov, 1962; Gaisky, 1997; Golenetskii, 1977; Sankov et al., 1991; Kochetkov et al., 1977; Solonenko N.V., Solonenko A.V., 1987; Melnikova et al., 2010; Radziminovich et al., 2013]. В этом ряду особо стоит работа иркутского сейсмолога К.В. Пшенникова [Pshennikov, 1965], в которой не только обобщены известные на тот период данные об афтершоках, но и предпринята попытка объяснить их возникновение уменьшением вязкости среды в очаге сильного землетрясения.

Проблемой выделения последовательностей взаимосвязанных событий в БРЗ занималась Н.С. Боровик 
[Borovik, 1970, 1972, 1978]. Площадь, занятая афтершоками и роями, определялась ею по сгущению их эпицентров, но для выделения афтершоковых и роевых серий во времени использовался разный подход. Для оценки длительности афтершоковой активности предлагалось сравнивать средние значения суммарной энергии землетрясений, выделенной за определенный промежуток времени в области очага рассматриваемого главного толчка, тогда как для роев ориентиром служило среднее число толчков в единицу времени. Н.С. Боровик выделяла также группы землетрясений, под которыми понимались совокупности из двух-трех слабых толчков, произошедших на площади радиусом до 10 км (максимальная погрешность определения эпицентров для основной части БРЗ в тот период времени) в течение не менее трех часов. Если выборка состояла из четырех землетрясений и более, то она относилась к роевой последовательности.

Последней наиболее полной и обобщающей работой, посвященной афтершоковым и роевым последовательностям землетрясений в БРЗ, является монография Н.В. Солоненко и А.В. Солоненко [Solonenko N.V., Solonenko A.V., 1987]. В работе были выделены афтершоковые последовательности для землетрясений с $\mathrm{K}_{\mathrm{p}} \geq 12.5$ и рои с $\mathrm{K}_{\mathrm{p}} \mathrm{max}>11.0$ за двадцатилетний период времени (с 1962 по 1982 г.). Выборки групп землетрясений производились на основании качественного сопоставления сейсмической активности в ареале группы и фоновой сейсмичности. Однако задачи, рассматриваемые в монографии, как пишут сами авторы, не требовали абсолютно точного оконтуривания пространственно-временных областей роев и афтершоков. Основное внимание было уделено сравнительному анализу условий возникновения и характера проявления афтершоковых последовательностей и роев землетрясений. Среди прочих был сделан вывод о пространственной разобщенности сильных толчков с афтершоками и роев землетрясений.

Цель данной работы заключалась в том, чтобы выделить из регионального каталога землетрясений БРЗ афтершоковые и роевые последовательности, проанализировать их пространственное распределение и оценить их вклад в сейсмический процесс.

\section{2. ДАННЫЕ И МЕТОДЫ}

Большую роль при декластеризации играют качество каталога (его представительность и полнота), а также точность локализации гипоцентров. В данной работе использовался региональный каталог землетрясений Байкальского филиала (для западной части территории использовались также данные Алтае-Саянского филиала) Геофизической службы СО РАН за период с 1962 по 2008 г., произошедших на территории, ограниченной координатами: $\varphi=50.0^{\circ}-60.0^{\circ}$ с.ш., $\lambda=96.0^{\circ}-$ $122.0^{\circ}$ в.д. Каталог нерелоцированный, однако он по- лучен по единой для всего региона и периода времени методике локализации эпицентров и определения энергетического класса $\mathrm{K}_{\mathrm{p}}$ (по номограмме Т.Г. Раутиан; далее по тексту будет обозначаться как К). Точность определения горизонтальных координат землетрясений в большинстве случаев находится в пределах 5 км. Глубина очагов вследствие больших ошибок определения в каталоге не указывается; укажем только, что наиболее сейсмоактивным является диапазон глубин 10-25 км [Radziminovich, 2010].

Для построения карт представительности в Байкальском регионе используются графики дальности регистрации землетрясений разных энергетических классов по методике, описанной в [Mirzoev et al., 2000]. Значимое изменение условий регистрации произошло в начале 2000-х годов с переходом на цифровую запись, что привело к увеличению числа надежно регистрируемых событий младших классов. В соответствии с картой представительности (карта доступна на сайте Байкальского филиала ГС СО РАН http://www.seis-bykl.ru), мы анализировали землетрясения с $\mathrm{K} \geq 6.6$ ( $\mathrm{K} \geq 7$ до 1982 г., когда была введена точность определения класса до десятичного знака). Согласно работе [Mel'nikova et al., 2010], события 7-го класса были представительны для землетрясений непосредственно БРЗ (то есть для районов рифтовых впадин и их ближайшего горного окружения) и для периода аналоговой регистрации, что подтверждается графиком повторяемости для того периода. Тем не менее необходимо отметить, что специальные исследования представительности каталога БРЗ и пространственно-временной изменчивости этого показателя не проводились, поэтому принятое для анализа значение $\mathrm{K} \geq 6.6$, возможно, для некоторых районов и некоторых периодов времени является переоцененным.

В качестве предполагаемых главных толчков из каталога были отобраны события с $\mathrm{K} \geq 12.5$; всего таких событий оказалось 177 (рис. 1). Сильнейшим событием за рассматриваемый период на данной территории является Тас-Юряхское землетрясение с $\mathrm{M=7}$, произошедшее 18 января 1967 г. на левобережье р. Олекма в Становом нагорье. Землетрясение сопровождалось многочисленными афтершоками, только за первые двое суток было зарегистрировано около 400 толчков с $\mathrm{K}>7$ [Kochetkov et al., 1975]. Однако в региональном каталоге информация об афтершоках отсутствует, в связи с чем Тас-Юряхское землетрясение выпало из анализа. Таким образом, сильнейшими событиями в анализируемой выборке оказались Бусийнгольское землетрясение 1991 г. с Mw=6.3 и Култукское 2008 г. с $\mathrm{Mw}=6.2$.

Для выделения афтершоковых серий использовалась программа В.Б. Смирнова (МГУ им. М.В. Ломоносова), в которой реализован алгоритм, разработанный Г.М. Молчан и О.Е. Дмитриевой [Molchan, Dmitrieva, 1991, 1992]. Данный метод основан на поиске компромисса между ошибками двух родов: пропуск 


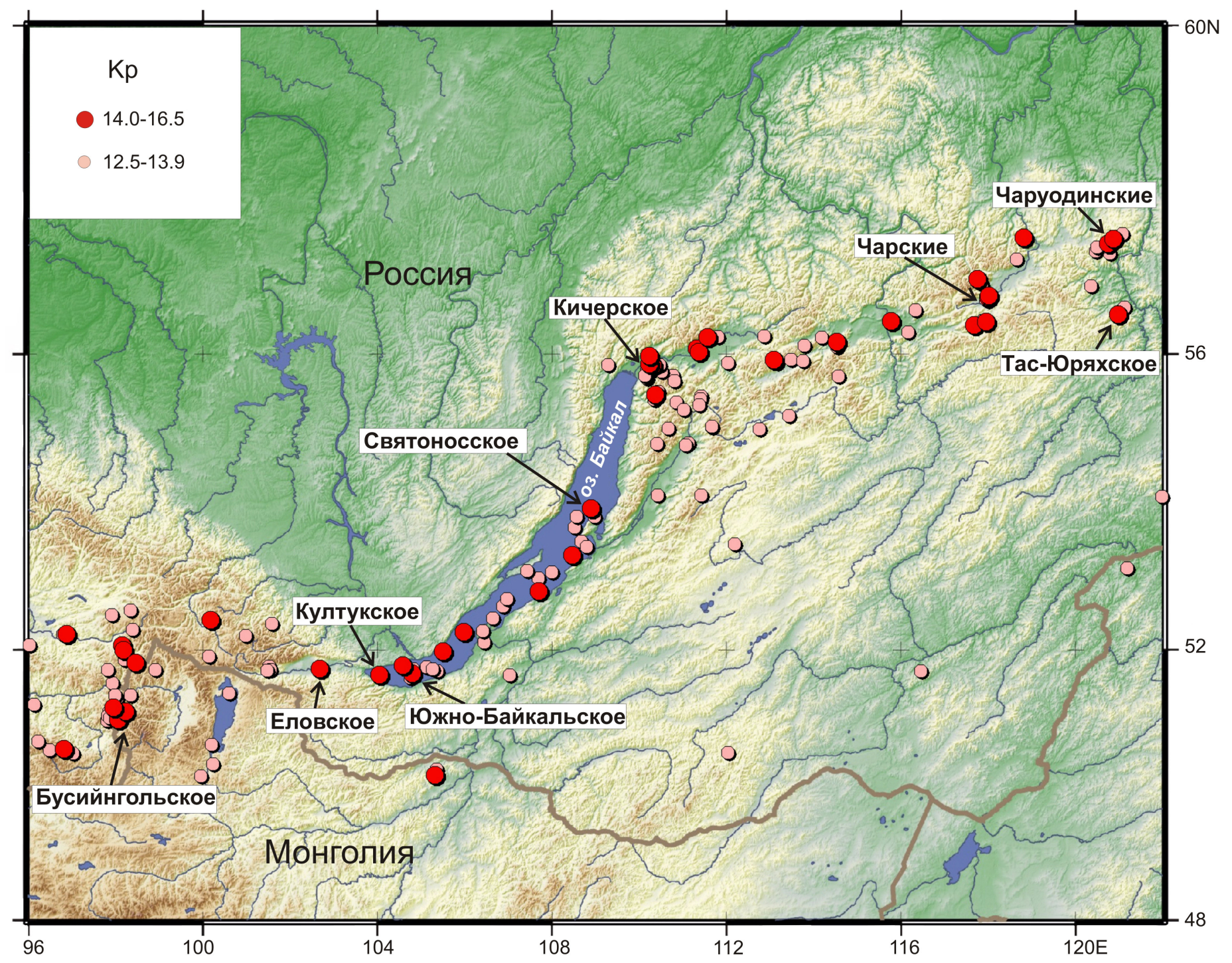

Рис. 1. Эпицентры землетрясений, протестированных на статус главного толчка и наличие афтершоков.

Даны названия землетрясений, упоминающихся в тексте.

Fig. 1. Epicentres of earthquakes studied for the status of main shock and presence of aftershocks.

Earthquakes' names are given in the text.

афтершоков и, наоборот, захват фоновых событий в качестве афтершоков. Для выборки афтершоков учитывается их распределение в пространстве (эллиптическое рассеяние) и по времени (в соответствии с законом Омори). Функции их распределения сравниваются с таковыми для фоновой сейсмичности. Программа, основанная на этом методе, успешно применялась для декластеризации каталогов Северного Кавказа [Smirnov, Gabsatarova, 2000], Курильского региона [Andreeva et al., 2009] и Камчатки [Saltykov, Kravchenko, 2010; Baranov, Chebrov, 2012].

Для контроля работы программы афтершоки выбирались также вручную с использованием программы визуализации сейсмического процесса «EQ», разработанной в ИЗК СО РАН (авторы: И.Г. Менакер, Е.А. Ле- вина, В.В. Данилов). Очевидно, что и при формальной процедуре очистки каталога, и при интуитивном ручном способе абсолютно корректная идентификация афтершоков невозможна.

Выделение роев землетрясений - задача, еще более неопределенная в силу отсутствия четкой привязки к главному толчку, поэтому в настоящей работе выбирались только те роевые последовательности, в которых есть события с $\mathrm{K} \geq 11.0$. Такой же подход к выделению роев (а также к выбору землетрясений с $\mathrm{K} \geq 12.5$ в качестве главных толчков для афтершоковых серий) был использован в работе [Solonenko N.V., Solonenko A.V., 1987]. Для отбора роев использовался каталог, уже очищенный от афтершоков. Затем все оставшиеся события с $\mathrm{K} \geq 11.0$ рассматривались отдельно также с ис- 


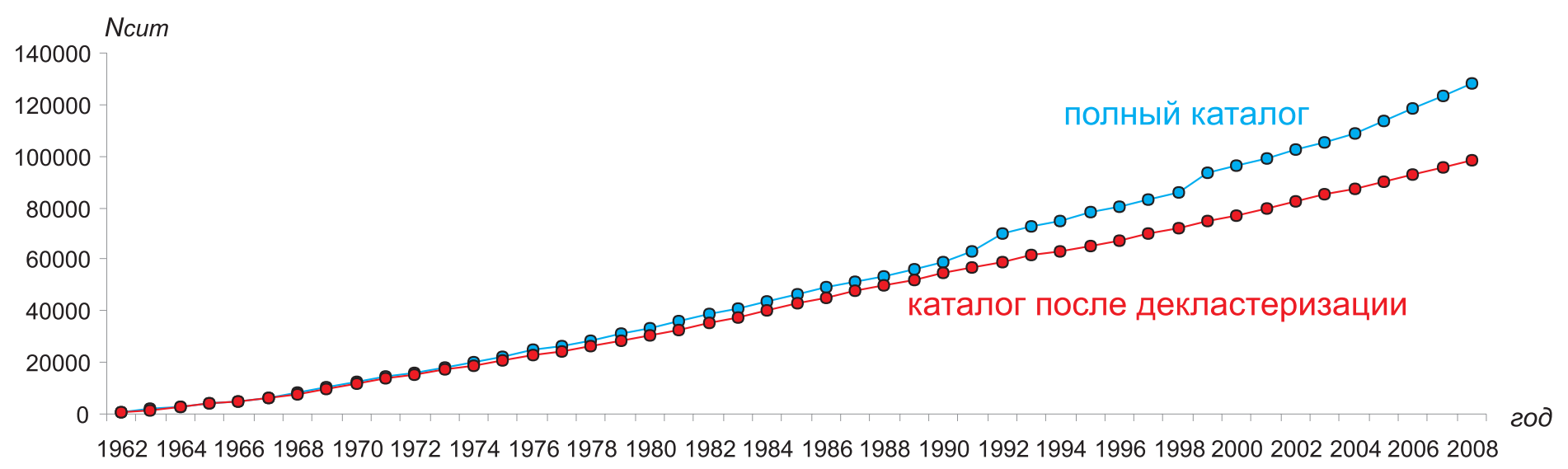

Рис. 2. Кумулятивные графики числа землетрясений для полного и декластеризованного каталогов.

Fig. 2. Cumulative curves of the number of earthquakes as per records in the complete and declastered catalogues.

пользованием вышеупомянутой программы визуализации каталога. В качестве роев выбирались совокупности, состоящие из не менее чем 10 толчков, образующих единое эпицентральное поле в определенный промежуток времени.

\section{3. РЕЗУЛЬТАТЫ}

Результаты декластеризации показали, что афтершоки землетрясений с $\mathrm{K} \geq 12.5$ составляют примерно

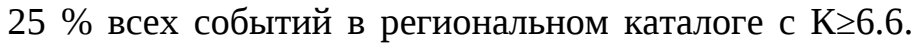
Как видно из рис. 2, кумулятивные графики полного и «очищенного» каталогов до середины 1970-х годов фактически совпадают. На графике полного каталога четко выражены две ступени, связанные с интенсивными афтершоковыми сериями: в 1992 г. за счет многочисленных афтершоков Бусийнгольского землетрясения 27.12.1991 г., Mw=6.3, и в 1999 г. в результате двух землетрясений с Mw=6.0: Южно-Байкальского 25 февраля и Кичерского 21 марта. Собственно, именно после 1992 г. и начинается значимое расхождение графиков. Действительно, Бусийнгольское и Кичерское землетрясения, будучи лидерами по числу повторных толчков, внесли основной вклад в процент афтершоков от всех событий каталога.

Всего из 177 проанализированных землетрясений статус главных толчков получили 126 событий, остальные сами являлись афтершоками более сильных землетрясений. В случае ручной выборки число главных толчков оказалось меньше по причине субъективной дефиниции разного рода группирующихся событий. Например, следуя стереотипу и принятым определениям, мы отделяем форшоки и/или рои от афтершоков. В этом смысле формальное выделение главных толчков более оправданно и точно по смыслу, поскольку, строго говоря, и в форшоковых сериях, и в роевых последовательностях могут быть сильные толчки, сопровождавшиеся своими афтершоками. В связи с этим, в данном случае будем считать, что выделено 126 главных событий.

Из данных 126 землетрясений афтершоками сопровождалось 93 толчка (рис. 3). Однако при сравнении с результатами ручной выборки было выяснено, что только после 12 землетрясений действительно не было афтершоков, по крайней мере с $\mathrm{K} \geq 6.6$. Остальные характеризовались малым количеством повторных толчков - от 1 до 12 событий. Таким образом, если приравнивать малое количество афтершоков (до 12) к их фактическому отсутствию, то афтершоками сопровождалось $74 \%$ землетрясений с $\mathrm{K} \geq 12.5$; если же подходить более строго и учитывать даже единичные повторные события, то таковых будет уже 90 \% (114 из 126 толчков). Все относительно сильные землетрясения сопровождались афтершоками, но следует отметить два события с $\mathrm{K}=14$ : землетрясение 09.08.1972 г. с эпицентром в центральной части оз. Байкал, которое было одиночным, и Еловское землетрясение 29.06.1995 г. в Тункинской впадине, характеризовавшееся малым количеством афтершоков, к тому же достаточно «разбросанных» и удаленных от главного толчка, что дало основание усомниться в их афтершоковой природе [Golenetskii, 2001]. С понижением класса главного толчка снижается и процентное отношение событий, сопровождавшихся афтершоками. С одной стороны, это объясняется тем, что для слабых событий области подготовки и релаксации напряжений меньше и, соответственно, меньше воздействие главных толчков на соседние разломы. С другой стороны, этот факт может быть следствием вводимого в анализ значения порогового класса: чем меньше класс главного толчка, тем более должен быть снижен класс землетрясений, рассматриваемых в качестве предполагаемых афтершоков, что, к сожалению, ограничивается уровнем представительности каталога. Наши результаты показывают, что среди землетрясений с $13.0 \leq \mathrm{K} \geq 13.486$ \% событий бы- 


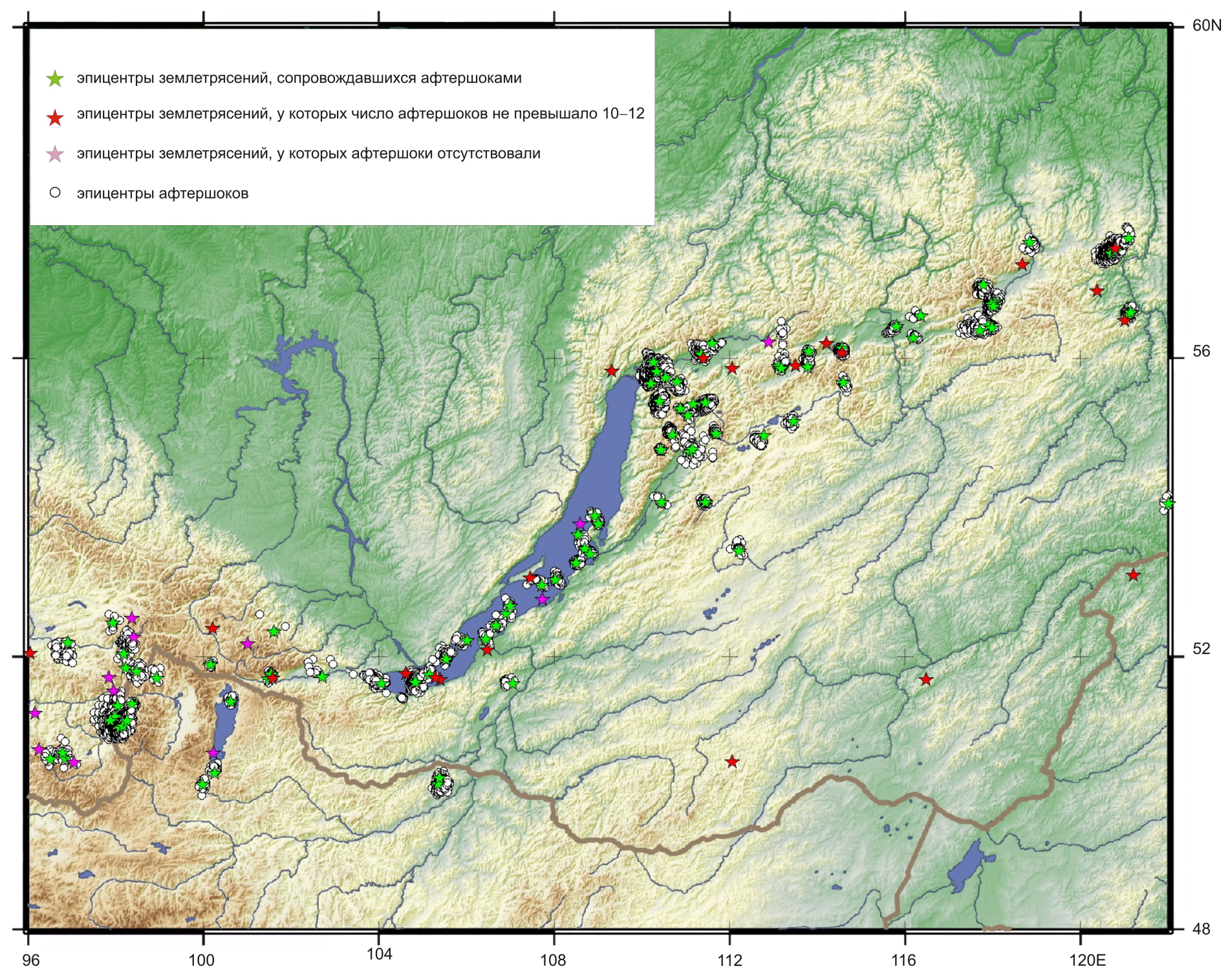

Рис. 3. Афтершоковые последовательности, выделенные по программе В.Б. Смирнова.

Звездочками отмечены главные толчки (с $\mathrm{K} \geq 12.5)$.

Fig. 3. Aftershock sequences revealed by the software developed by V.B. Smirnov.

Main shocks $(K \geq 12.5)$ are marked by stars.

ли с афтершоками, а среди $12.5 \leq \mathrm{K} \geq 12.9-76 \%$.

Другим нюансом, выявленным при использовании программы для декластеризации каталога, является тенденция к захвату большего числа афтершоков во времени по сравнению с ручной выборкой. В качестве яркого примера можно указать последовательность для землетрясения 31 августа 1968 г. с K=14, произошедшего в Муйской впадине. При визуальном анализе было выделено 26 афтершоков, затухание активности которых произошло фактически через месяц, тогда как по результатам формальной выборки афтершоки продолжались 970 суток и их общее количество достигло 51. Понятно, что столь малое количество афтершоков неизбежно оказывается «размазанным» на таком дли- тельном отрезке времени и вряд ли может соответствовать типичной картине затухания афтершоков. На рис. 4 видно, что непосредственные афтершоки действительно завершились в течение месяца после главного толчка, а последующие толчки в эпицентральной области произошли после перерыва в несколько месяцев. Другой пример - землетрясение 31 мая 2000 г. с $\mathrm{K}=13.4$, произошедшее в эпицентральной области Южно-Байкальского землетрясения с $\mathrm{Mw}=6.0$. Толчок 31.05.2000 г. формально определяется как его афтершок, но и в этом случае наблюдается большой перерыв между спаданием активности непосредственных афтершоков и данным толчком. Отметим, кстати, что и само землетрясение 31 мая сопровождалось собствен- 


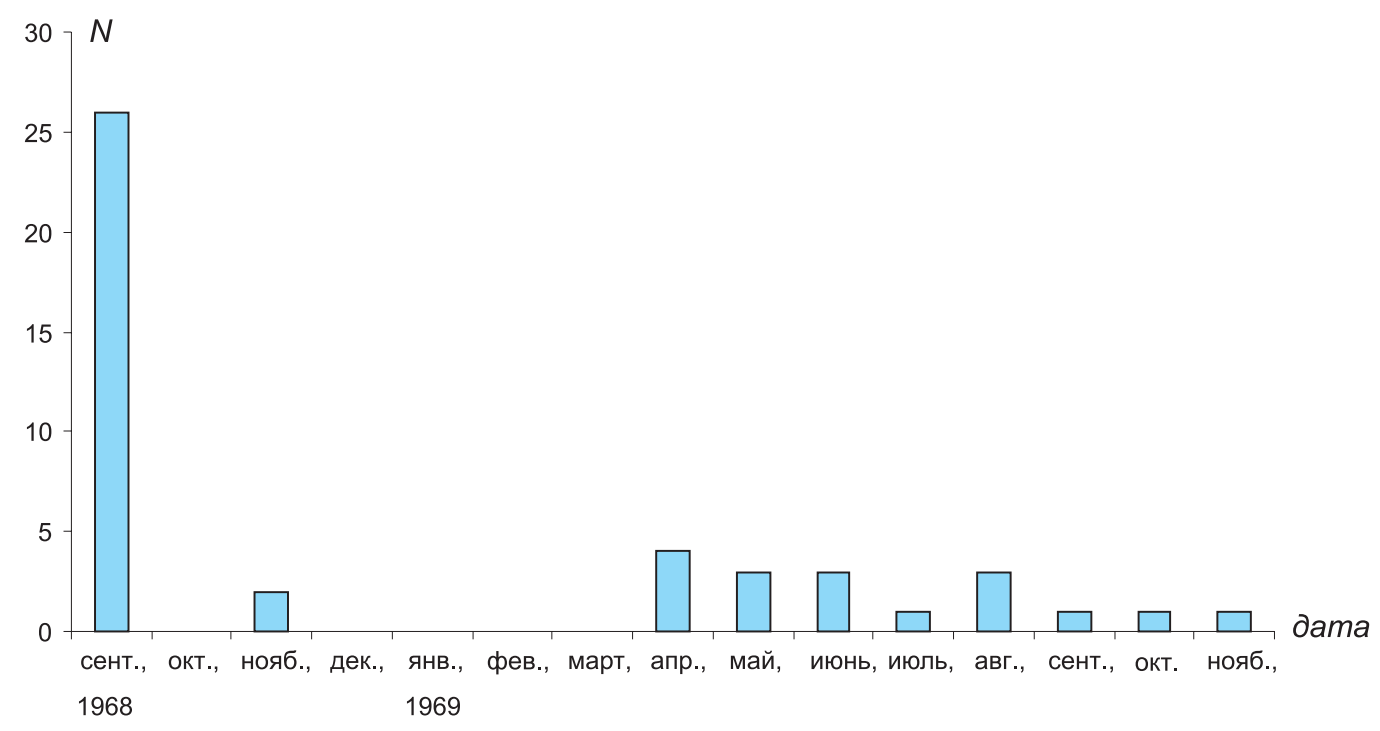

Рис. 4. Гистограмма распределения числа повторных толчков для землетрясения 31.08.1968 г.

В столбец «сентябрь 1968 г.» включены и толчки 31 августа 1968 г.

Fig. 4. The histogram showing distribution of the number of aftershocks for the earthquake of 31 August 1968.

Data on shocks that occurred on 31 August 1968 are also included in column «September 1968».

ными афтершоками. В приведенных примерах отчетливо видно, что сильное землетрясение может приводить не только к возникновению непосредственных афтершоков, но и к последующей активизации в его эпицентральной области.

По пространственному критерию выборки афтершоков с использованием программы можно отметить небольшую зависимость результата от размера заданного района для анализа, что, вероятно, связано с различием в оценке фоновой сейсмичности.

Результаты показывают, что землетрясения югозападного фланга БРЗ характеризуются меньшим числом повторных толчков по сравнению с территорией к северо-востоку от оз. Байкал (см. рис. 3). Это относится, в первую очередь, к району Тункинских впадин, но и в пределах впадин Северной Монголии, которые, по мнению многих исследователей, также относятся к БРЗ, велико число «одиночных» событий. Исключением являются землетрясения, произошедшие в Бусийнгольской впадине и ее окрестностях. Относительно малое количество повторных толчков характерно и для Южного Байкала. Например, Южно-Байкальское землетрясение 1999 г. с Mw=6.0 сопровождалось более чем 800 афтершоками, в то время как Кичерское событие 1999 г. (с эпицентром в одноименной впадине к северу от Байкала) такой же магнитуды вызвало чуть менее 5000 афтершоков. После сильнейшего за инструментальный период наблюдений землетрясения на юге Байкала, Култукского 2008 г. с $\mathrm{Mw}=6.2$, было идентифицировано всего 423 повторных толчка. Еще раз отметим, что, говоря об отсутствии или малочисленности афтершоков, подразумеваем только земле- трясения начиная с представительного класса. Вполне возможно, что истинно «одиночных» сильных и умеренной силы коровых землетрясений не бывает вообще. При благоприятных условиях регистрации, как в случае с Култукским землетрясением, удалось снизить представительный класс до $\mathrm{K} \geq 4$, и в общей сложности было записано 1790 афтершоков [Melnikova et al., 2012]. Однако в данной работе мы вынуждены оперировать событиями, как уже упоминалось, с K $\geq 6.6$, т.е. единым уровнем для всех рассматриваемых последовательностей.

Результаты выделения роев представлены на рис. 5. Всего по описанным выше критериям выделено 39 роев. Среди них находится Олдонгсинский рой $1997-$ 1999 гг. на северо-восточном замыкании БРЗ (рис. 5 и 6a). Ситуация интересна тем, что при декластеризации два сильнейших события данной последовательности, 24.10.1997 г. с K=13.0 и 08.09.1999 г. с K=13.3, определены как главные толчки с афтершоками. Действительно, распределение числа последующих толчков после этих сильнейших землетрясений, по крайней мере на начальной стадии, подчиняется закономерностям, присущим афтершоковым сериям (рис. 6г). Более того, из рис. 6в видно, что между этими двумя активизациями был небольшой период затишья. Однако, исходя из распределения землетрясений по классам, компактности в пространстве и времени данная последовательность классифицировалась как роевая [Radziminovich et al., 2004, 2006; Kozmin, 2003]. Дополнительную сложность в определение типа активности добавляет тот факт, что землетрясение 24.10.1997 г. было не первым в последовательности: активизация 


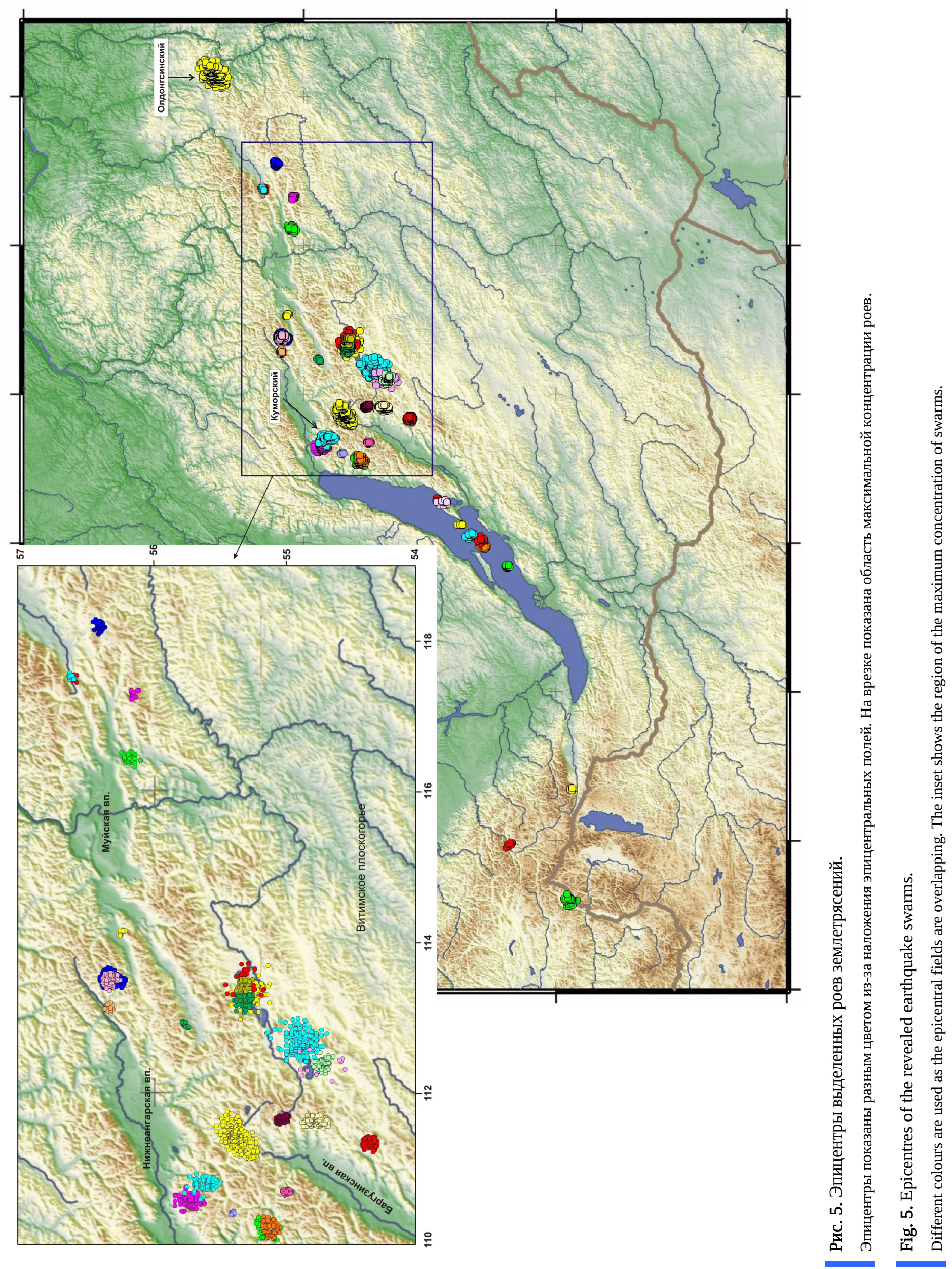



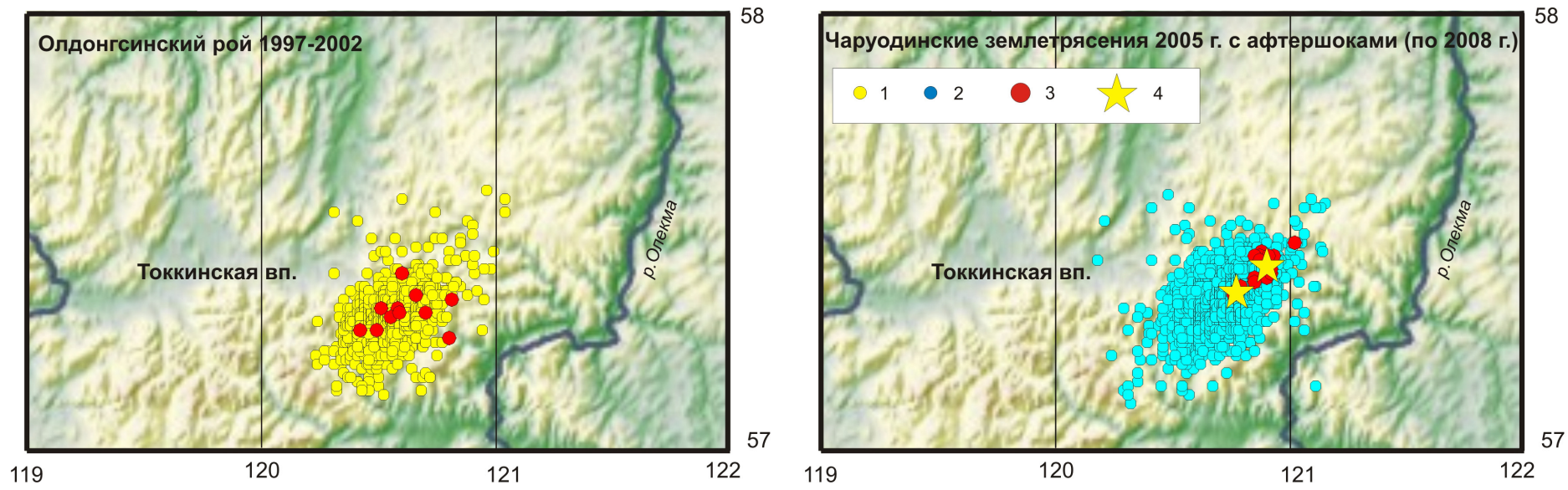

Рис. 6а. Эпицентральные поля Олдонгсинского роя и афтершоков Чаруодинских землетрясений.

1 - эпицентры роя; 2 - эпицентры афтершоков; 3 - землетрясения с K>12; 4 - эпицентры главных толчков.

Fig. 6a. Epicentral fields of the Oldongsinsky swarm of earthquakes and aftershocks of the Charuodinsky earthquakes.

1 - epicentres of the swarm; 2 - epicentres of the aftershocks; 3 - earthquakes with $\mathrm{K}>12$; 4 - epicentres of main shocks.

началась в конце сентября - начале октября 1997 г., что может трактоваться как в пользу роя, так и в пользу форшоковой-афтершоковой серии. Олдонгсинский рой землетрясений практически затух к 2003 г., но в 2005 г. в этом же месте произошли два сильных толчка: 10 ноября с $\mathrm{Mw}=5.8(\mathrm{~K}=15.7)$ и 11 декабря с $\mathrm{Mw}=5.6$ (K=14.8) (рис. 6а, 6б). Землетрясения названы Чаруодинскими [Radziminovich et al., 2006]. На возможную связь всех перечисленных событий указывает единство эпицентральной области, а также тот факт, что до 1997 г. непосредственно в этом районе фоновая активность за инструментальный период была низка. Таким образом, эти сейсмические последовательности если и не взаимосвязаны, то, по меньшей мере, являются единым процессом деструкции земной коры в данном районе.

Другим примером роя, состоящего из активизаций, связанных с сильнейшими толчками в последовательности, служит Куморский рой землетрясений 19661967 гг. В рое было 2 толчка 13-го класса и 4 землетрясения с $\mathrm{K}=11$, причем три из них произошли до первого сильнейшего события. Из рис. 7 видно, что пики на графике количества землетрясений совпадают с пиками по энергии, т.е. с сильнейшими событиями.

Типичные рои, в которых не наблюдается закономерного распределения землетрясений по количеству

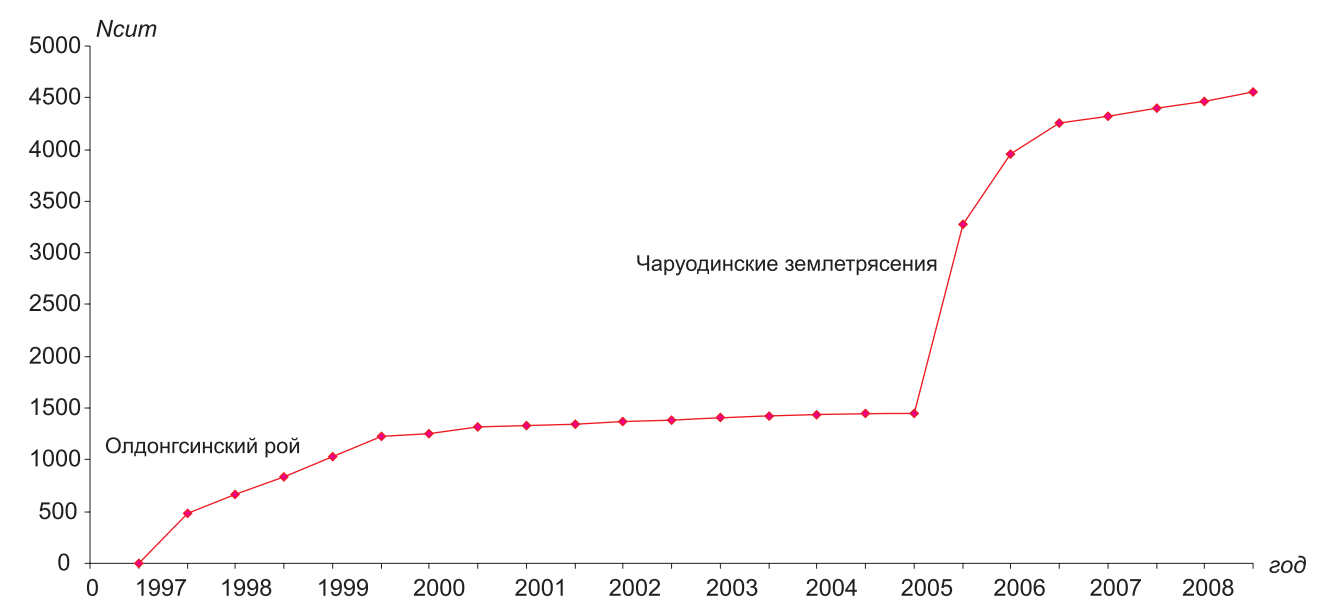

Рис. 6б. Кумулятивный график числа землетрясений в эпицентральной области рассматриваемых последовательностей.

Fig. 6б. The cumulative curve of the number of earthquakes in the epicentral area of the sequences under study. 

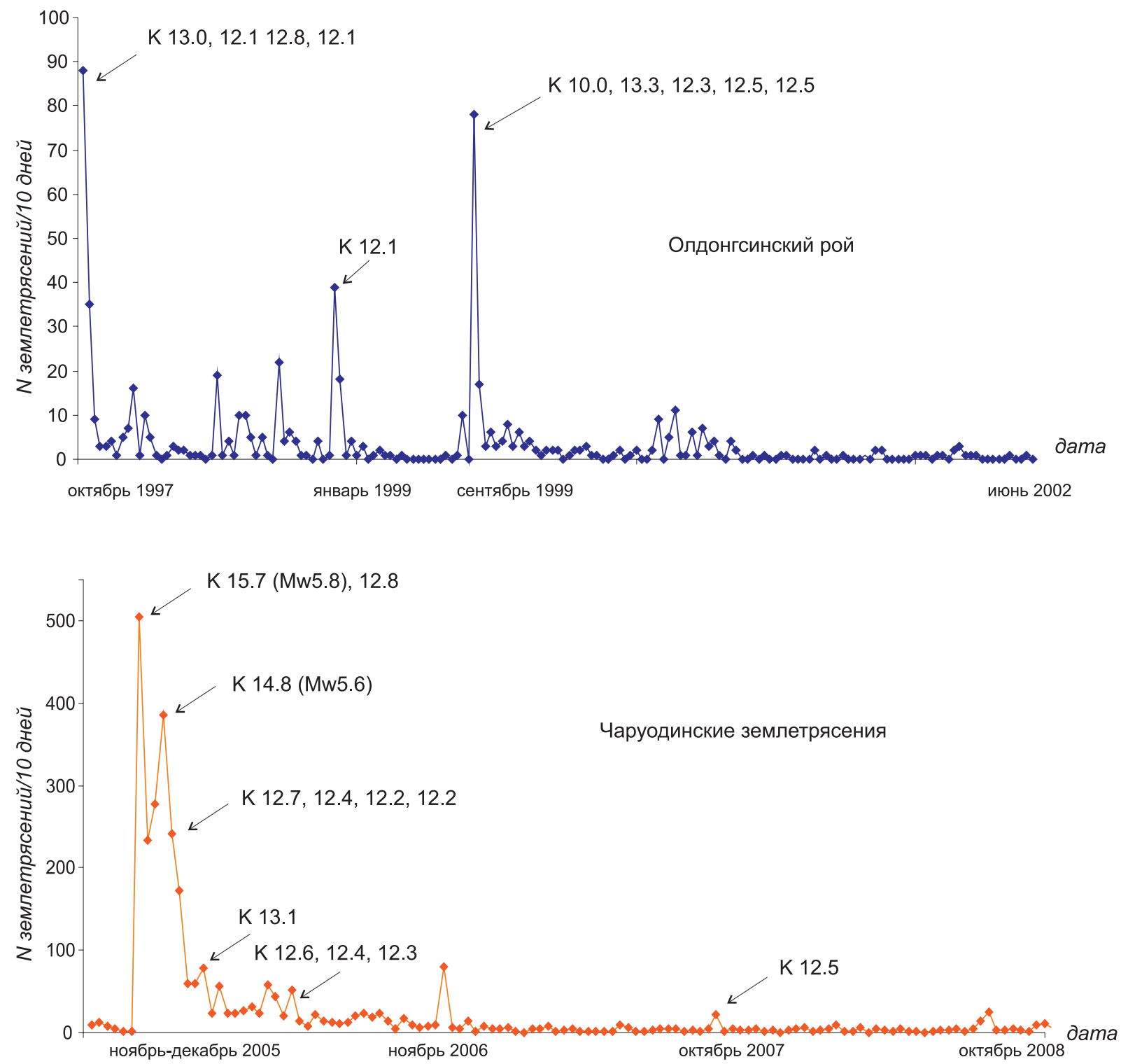

Рис. 6в. Распределение числа землетрясений по 10 дней в Олдонгсинском рое и Чаруодинской афтершоковой серии.

Стрелками указаны пики, обусловленные событиями с К>12. Графики показывают различие в распределении числа толчков и сильных землетрясений в роевой и афтершоковой последовательностях.

Fig. 6в. Distribution of the number of earthquakes by 10-day period in the Oldongsinsky swarm and the Charuodinsky aftershock series.

Arrows indicate peaks due to events with $\mathrm{K}>12$. The curves show the difference in distribution of the number of strong earthquakes and aftershocks in the swarm and aftershock sequences.

и энергии, также имеют место быть в сейсмическом процессе БРЗ. Но все же они более характерны для последовательностей, состоящих из толчков только слабых классов.

В данной работе не рассматривался сейсмический режим перед сильными землетрясениями, поэтому мы не выделяли форшоки. Однако стоит отметить, что полученные предварительные результаты [Radziminovich et al., 2008] показали, что непосредственные форшоки обычно малочисленны (от нескольких событий до нескольких десятков) и вероятность их возникнове- ния выше, если перед этим в эпицентральной области будущего главного толчка была активизация либо в виде роя, либо в виде предыдущего недавнего сильного землетрясения с афтершоками, например в случае парных событий (Чарские события 24 апреля с $\mathrm{Mw}=5.4$ и 22 августа с $\mathrm{Mw}=6.0$ в 1994 г. или же Чаруодинские толчки 2005 г.). В районах с постоянно повышенной сейсмической активностью форшоки часто не наблюдаются вовсе. Здесь, вероятно, среда уже достаточно раздроблена и фоновые события принимают на себя роль форшоков. Ситуация осложняется тем, что в 

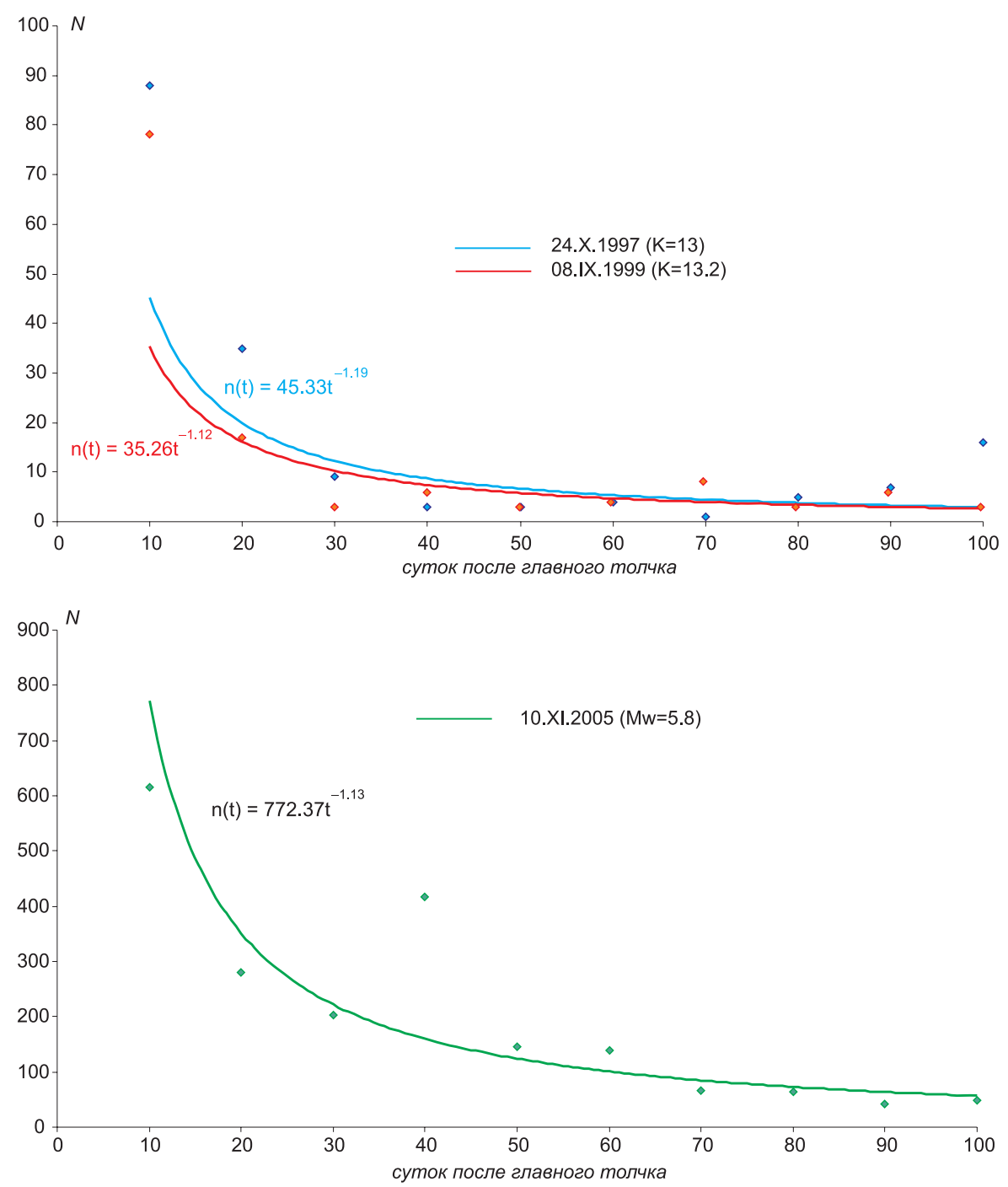

Рис. 6г. Затухание повторных толчков для сильнейших землетрясений Олдонгсинского роя (вверху) и Чаруодинского события (внизу).

Fig. 6г. Decay of repeated shocks of the strongest earthquakes of the Oldongsinsky swarm (top) and the Charuodinsky seismic event (bottom).

таких районах трудно отличить форшоки от фона. Наряду с активизацией перед возникновением сильных землетрясений нередко отмечается эффект сейсмического затишья. Эта закономерность выявлена ранее для Прибайкалья, в том числе и для средних по силе $(\mathrm{M}<6)$ событий [Borovik, 1970]. Однако уверенно выделить долговременные затишья, связанные с подготовкой сильного события, нам удалось только в нескольких случаях, причем на фоне затишья главные толчки происходили без форшоков.

\section{4. ОБСУЖДЕНИЕ РЕЗУЛЬТАТОВ}

Несмотря на то, что метод Г.М. Молчан и О.Е. Дмитриевой «наиболее эффективен для выделения больших афтершоковых последовательностей» [Molchan,
Dmitrieva, 1991], сравнение с результатами ручной выборки показало его применимость и для событий с $\mathrm{M} \geq 4.7$. Сопоставление также показало, что разница в числе выделенных афтершоков находится в пределах 2 \% (24-26 \%), что является очень высоким показателем. Таким образом, программа В.Б. Смирнова подходит для декластеризации каталога БРЗ в целом, а также для статистического анализа параметров выделенных последовательностей. Вместе с тем, в случае изучения индивидуальных афтершоковых серий, визуальный контроль (или ручная выборка) все же необходим, тем более что в условиях БРЗ, где на сегодняшний день магнитуда сильнейших землетрясений за период инструментальных наблюдений не превышала 7, это не составляет особых сложностей по сравнению, например, с зонами субдукции, где афтершоки сильнейших землетрясений исчисляются тысячами и процесс релак- 

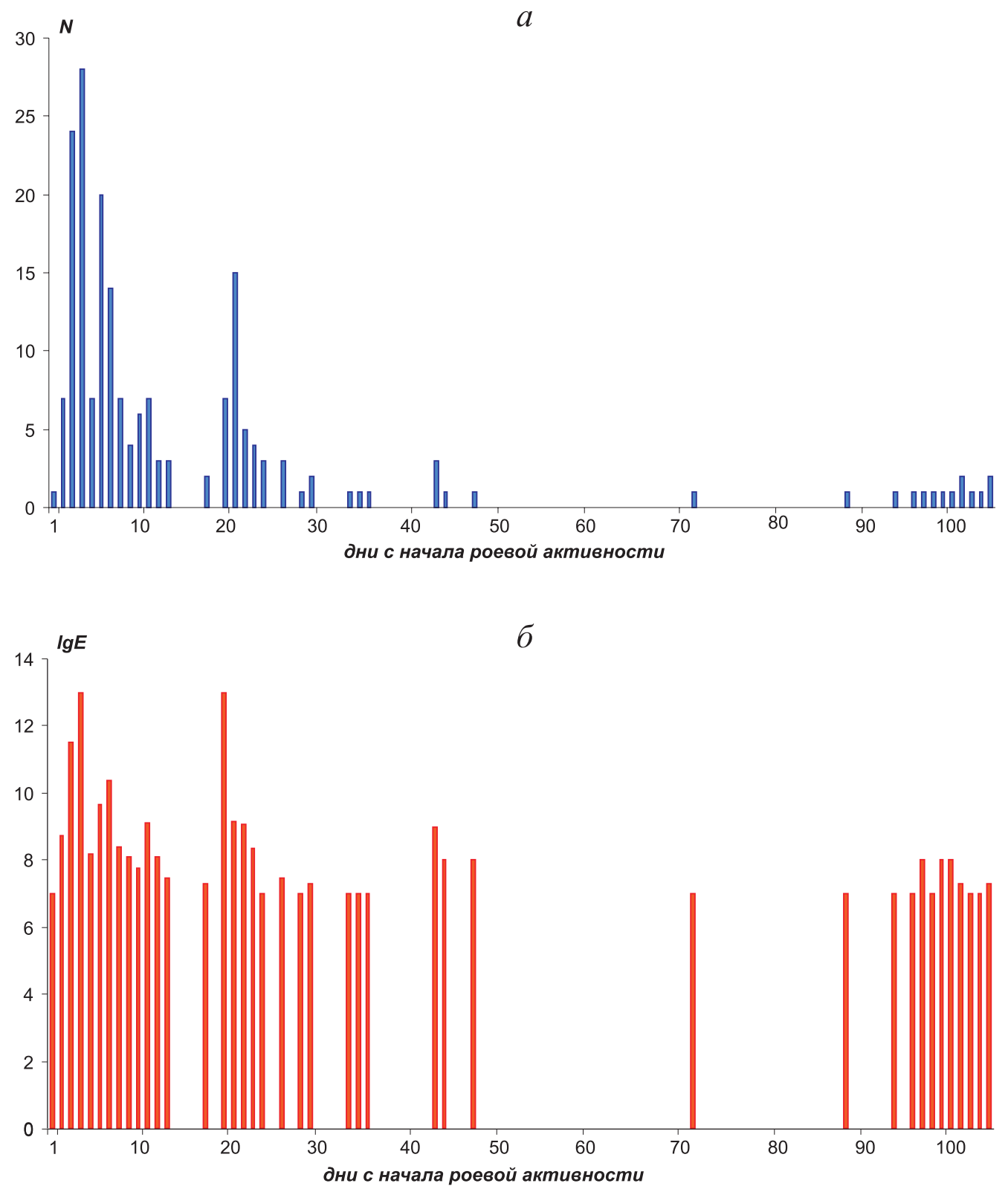

Рис. 7. Распределение числа толчков (а) и логарифм (б) энергии для Куморского роя землетрясений 1966-1967 гг.

Эпицентральное поле роя показано на рис. 6.

Fig. 7. Distribution of shocks (a) and the energy logarithm (б) for the Kumorsky swarm of earthquakes of $1966-1967$.

The epicentral field of the swarm is shown in Figure 6.

сации может длиться годами.

Результаты декластеризации показали, что четверть всех событий в региональном каталоге с $\mathrm{K} \geq 7(6.6)$ составляют афтершоки землетрясений с $\mathrm{K} \geq 12.5$. Для сравнения приведем данные из работы [Hutton et al., 2010], согласно которым в каталоге Южной Калифорнии 48 \% всех землетрясений являются форшоками и афтершоками сильных толчков. При этом, однако, подавляющее большинство повторных толчков принадлежало трем землетрясениям с М>7. В нашем случае половину всех афтершоков «обеспечили» три землетрясения: Бусийнгольское, Кичерское и Чаруодинское.
Следует отметить, что два последних землетрясения не являются самыми сильными из всех проанализированных, хотя в целом для байкальских землетрясений подтверждается зависимость числа афтершоков от магнитуды главного толчка [Ochkovskaya, Radziminovich, 2011]. Но для всех трех событий характерно то, что им сопутствовала длительная активизация, часто роевого характера. О Чаруодинском землетрясении говорилось выше. В области Кичерского события после 1999 г. активность фактически не прекращалась, по меньшей мере, до 2010 г. Наглядное представление об этом могут дать карты ежегодной сейсмичности с 
1993 г., приведенные на сайте БФ ГС РАН. Наиболее значимым землетрясением после 1999 г. в эпицентральной области Кичерского толчка стало Акуликанское событие 4 декабря 2006 г. с Mw=5.2 (рис. 8). После него было зарегистрировано полторы тысячи повторных толчков в течение трех последующих лет. Особенности развития афтершокового процесса Бусийнгольского землетрясения подробно рассмотрены в работах новосибирских сейсмологов [Emanov et al., 2005, 2006]. Авторы отмечают, что данный толчок послужил началом изменения сейсмического режима Бусийнгольской впадины и ее восточного борта как минимум на два десятилетия. При этом сам афтершоковый процесс является частью сейсмической активизации сопряженных тектонических структур. Активизация носила пульсирующий характер, который выражался в резком изменении числа событий, но не их энергии. Пульсации не соответствовали закону Омори, а их интенсивность менялась во времени без видимой закономерности.

Помимо таких длительных активизаций в некоторых случаях наблюдается возрастание фоновой активности после сильного толчка с афтершоками по сравнению с периодом, предшествующим землетрясению (рис. 8). Для умеренных по силе землетрясений БР3 картина не настолько яркая, как для землетрясений с магнитудой 8.0 и выше [Romashkova, Kossobokov, 2001], но тем не менее это может привести к увеличению числа афтершоков при их формальном выделении. Выходом в данной ситуации может служить введение в алгоритм декластеризации такого параметра, как время между соседними (последовательными) событиями.

Приведенные выше примеры дают представление, насколько сложно разделить последовательности на форшоковые, афтершоковые и/или роевые. Практика показывает, что только лишь параметр разницы магнитуд между сильнейшими событиями в последовательности (например, С.С. Арефьев [Aref'ev, 2002] в качестве магнитудной границы между роями и афтершоками предлагал значение $\mathrm{dM}=0.4$ ) не всегда может служить индикатором типа последовательности. Рассмотренные рои землетрясений БРЗ условно можно разделить на два типа: типичные рои (в данном случае не связанные с активной вулканической деятельностью) и рои, в которых наблюдаются афтершокоподобные паттерны, т.е., по сути, рои представлены несколькими «главными» толчками со своими афтершоками. Более того, на таком представительном материале, как рои Коринфского рифта, показано, что даже в независимых роях характер изменения параметров сейсмического режима (активизация и спад активности) аналогичен процессу подготовки сильного землетрясения и афтершоковой релаксации [Potanina et al., 2011].

Возможно, отнесение последовательности к роевой или форшоково-афтершоковой не столь принципиаль- но, если, конечно, речь не идет о прогнозе сильного землетрясения. Тем не менее определение типа сейсмической активизации имеет большее значение для понимания особенностей деструкции земной коры в конкретном районе, поскольку существуют модели, предполагающие связь между типом последовательности землетрясений и состоянием среды (по степени раздробленности) и приложенным напряжением. Так, согласно К. Моги [Mogi, 1963], главный толчок с последующими афтершоками происходит в условиях относительно однородной малонарушенной среды и постоянного тектонического напряжения, тогда как рои в сильно раздробленной среде и при направленном «концентрированном» приложении напряжения, как в случае движения магмы и пр.

Возможно, именно разное состояние среды по степени нарушенности (раздробленности) является объяснением того, что рои в БРЗ происходят в основном к северо-востоку от озера Байкал, где к тому же отличаются многочисленные афтершоки для землетрясений даже невысокого класса. И наоборот, имеется тенденция к относительно малому количеству афтершоков у землетрясений юго-западного фланга БРЗ. Вывод об отсутствии или малочисленности афтершоков у землетрясений Тункинского района и Южного Байкала был сделан еще в монографии А.В. Солоненко и Н.В. Солоненко [Solonenko N.V., Solonenko A.V., 1987]. С.И. Голенецкий [Golenetskii et al., 1997] также отмечал, что данный факт «по-видимому, довольно характерен для землетрясений Южного Байкала». Ранее авторы [Ochkovskaya, Radziminovich, 2011] пытались объяснить это различным типом напряженного состояния земной коры: транспрессионным для юго-западного фланга и режимом растяжения земной коры для центральной части БРЗ. Однако для толчков высоких классов, к тому же со сдвиговым механизмом очага (более типичным при режиме транспрессии), характерно большее количество повторных толчков, что иллюстрируется Бусийнгольским землетрясением с $\mathrm{Mw}=6.3$.

Касаясь пространственного распределения роев, следует подчеркнуть, что большинство из них сосредоточено в области залегания обширного гранитного Ангаро-Витимского батолита, занимающего территорию к востоку от Северного Байкала. Трещинообразование в верхней части гранитного массива в условиях растяжения и наличие активной гидротермальной деятельности (а данный район как раз известен многочисленными выходами подземных вод) могут способствовать именно роевому типу сейсмической активности. Не следует исключать из рассмотрения и локальные условия, поскольку из врезки на рис. 5 видно, что во многих случаях рои происходят в одних и тех же местах.

Очевидно, что вышеизложенные предположения являются спекулятивными, и вопрос о пространственном распределении роев и численности афтершоков 

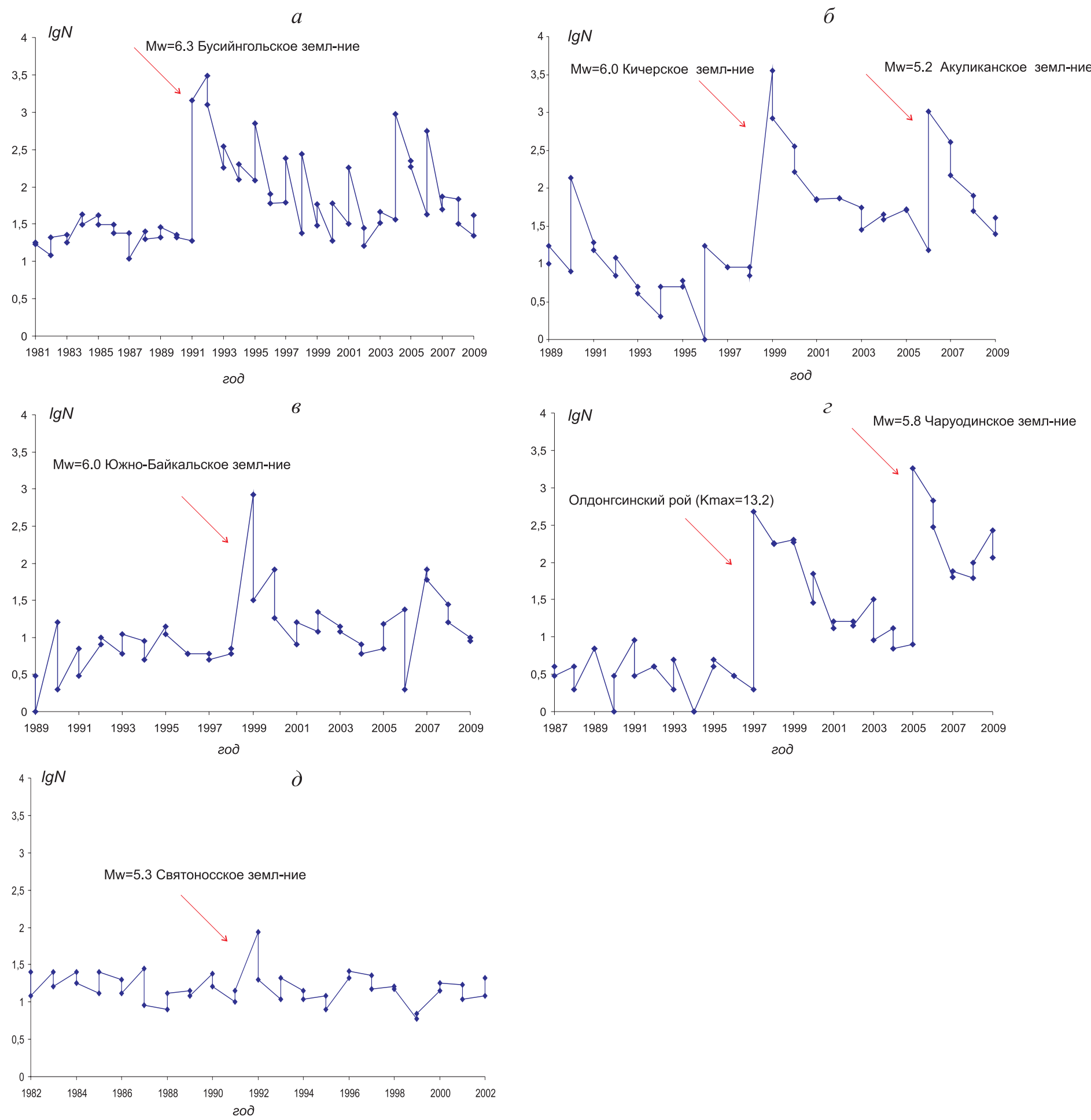

Рис. 8. Графики распределения числа землетрясений в окрестностях некоторых сильных толчков (примерно $\pm 0.3^{\circ}$ от эпицентра) по полугодовым интервалам времени в течение десяти лет до и после сильного события (в случае Бусийнгольского землетрясения график приведен до 2009 г.).

$a-2$ - графики повышения фонового уровня сейсмической активности после затухания непосредственных афтершоков; $\partial$ - пример возвращения сейсмической активности на фоновый уровень.

Fig. 8. Curves of distribution of the number of earthquakes in the vicinity of several strong shocks (about $\pm 0.3^{\circ}$ from the epicentre) in the six-month periods through ten years before and after the major event (in case of the Busiyngolsky earthquake, the curve is constructed for the data by 2009).

The curves in Figures $a, \sigma, в$ and 2 show the increase in the background level of seismic activity after the decay of immediate aftershocks; the curve in Figure $\partial$ shows an example how the seismic activity level returns to the background level. 
остается открытым. Однако вывод Н.В. и А.В. Солоненко о том, что в областях максимальной концентрации роев не происходят сильные толчки с афтершоками и наоборот, не подтверждается более длительным периодом наблюдений. На сегодняшний момент можно с уверенностью утверждать, что в БРЗ и рои, и сильные толчки с афтершоками могут происходить в одних районах и, более того, могут быть взаимосвязанными событиями.

\section{5. ЗАКЛЮЧЕНИЕ}

В данной работе была предпринята первая попытка декластеризации каталога БРЗ с использованием формализованного метода. Результаты показали высокую степень сходимости выделенных афтершоков по программе В.Б. Смирнова по сравнению с ручной выборкой. Более того, формализованный подход в некоторых случаях бывает более строгим, так как позволяет выделять главные толчки и в форшоковых, и в роевых сериях. В некоторых случаях наблюдается возрастание фоновой активности после сильного толчка с афтершоками по сравнению с периодом, предшествующим землетрясению, что затрудняет выделение непосредственных афтершоков.

Результаты декластеризации показали, что четвертую часть всех событий в региональном каталоге (начиная с $\mathrm{K} \geq 6.6$ ) составляют афтершоки землетрясений с $\mathrm{K} \geq 12.5$. При этом наибольший вклад составляют афтершоки Бусийнгольского, Кичерского и Чаруодинского землетрясений. Афтершоками сопровождались
90 \% всех землетрясений, рассматриваемых в качестве главных толчков.

Были выделены также рои землетрясений, в которых есть события с $\mathrm{K} \geq 11$. Задача разделения роевых (где есть достаточно сильные толчки) и форшоковыхафтершоковых событий не имеет однозначного решения. Отмечается, что рои могут состоять из нескольких «главных» толчков со своими афтершоками. Материалы наблюдений за пятидесятилетний период инструментальных наблюдений подтверждают сделанные ранее выводы о том, что рои в БРЗ происходят в основном к северо-востоку от озера Байкал, а также о тенденции к малому количеству афтершоков у землетрясений юго-западного фланга БР3. Предположительно это может указывать на степень раздробленности земной коры в разных условиях напряженно-деформированного состояния. Возможно, определенную роль в возникновении роев играет геологическое строение, а именно Ангаро-Витимский гранитный батолит. Результаты данной работы показывают, что и рои, и сильные толчки с афтершоками в БРЗ пространственно не разобщены, как это считалось в предыдущих работах по данным меньшего по длительности периода наблюдений.

\section{6. БЛАГОДАРНОСТИ}

Авторы выражают признательность кандидату физ.-мат. наук В.Б. Смирнову за предоставленную программу выделения афтершоков. Работа поддержана грантом РФФИ 12-05-91161-ГФЕН_а.

\section{7. ЛИТЕРАТУРА}

Andreeva M.Y., Levin B.W., Sasorova E.V., 2009. Peculiarities of the within-year distribution of earthquakes in the Kuril region. Russian Journal of Pacific Geology 3 (5), 491-500. http://dx.doi.org/10.1134/S181971400905011X.

Aref'ev S.S., 2002. Foreshocks, aftershocks, and swarms of earthquakes. Izvestiya, Physics of the Solid Earth 38 (1), 55-71.

Baranov S.V., Chebrov D.V., 2012. Modeling and forecasting the aftershock processes in Kamchatka. Izvestiya, Physics of the Solid Earth 48 (11-12), 817-828. http://dx.doi.org/10.1134/S1069351312110018.

Borovik N.S., 1970. On some characteristics of earthquake focal areas in the Pribaikalie. Fizika Zemli 12, 3-9 (in Russian) [Боровик Н.C. О некоторых характеристиках областей очагов землетрясений Прибайкалья // Физика Земли. 1970. № 12. С. 3-9].

Borovik N.S., 1972. Grouping of earthquakes in the Pribaikalie. In: Issues of Seismicity of Siberia. Institute of Geology and Geophysics, Novosibirsk, Part 2, p. 59-65 (in Russian) [Боровик Н.С. Группирование землетрясений Прибайкалья // Вопросы сейсмичности Сибири. Новосибирск: Институт геологии и геофизики, 1972. Часть 2. С. 59-65].

Borovik N.S., 1978. On the reliability of determination of sequences of related events in the Baikal rift zone and the possibility of their use for studies of the epicental field. In: Seismic and seismic-geological studies in the central area of BAM. Yakutsk Division of Siberian Branch of the USSR Academy of Sciences, Yakutsk, p. 51-57 (in Russian) [Боровик Н.С. О надежности выделения последовательностей взаимосвязанных событий в Байкальской рифтовой зоне и возможности их использования для исследований эпицентрального поля // Сейсмические и сейсмогеологические исследования на центральном участке БАМа. Якутск: ЯФ СО АН СССР, 1978. С. 51-57].

Deverchere J., Houdry F., Diament M., Solonenko N., Solonenko A., 1991. Evidence for a seismogenic upper mantle and lower crust in the Baikal rift. Geophysical Research Letters 18 (6), 1099-1102. http://dx.doi.org/10.1029/91GL00851.

Emanov A.F., Emanov A.A., Filina A.G., Leskova E.V., 2005. Spatial and temporal characteristics of seismicity of the AltaiSayan zone. Fizicheskaya Mesomechanika 1, 49-64 (in Russian) [Еманов А.Ф., Еманов А.А., Филина А.Г., Лескова E.B. Пространственно-временные особенности сейсмичности Алтае-Саянской складчатой зоны // Физическая ме- 
зомеханика. 2005. № 1. С. 49-64].

Emanov A.F., Emanov A.A., Filina A.G., Leskova E.V., Kolesnikov Yu.I., Rudakov A.D., 2006. General and individual features in development of aftershock processes of the strongest earthquakes in the Altai-Sayan mountain region. Fizicheskaya Mesomechanika 9 (1), 33-43 (in Russian) [Еманов А.Ф., Еманов А.А., Филина А.Г., Лескова Е.В., Колесников Ю.И., Рудаков А.Д. Общее и индивидуальное в развитии афтершоковых процессов крупнейших землетрясений Алтае-Саянской горной области // Физическая мезомеханика. 2006. Т. 9. № 1. С. 33-43].

Gaisky V.N., 1997. Statistical Studies of Seismic Regime. Nauka, Moscow, 123 p. (in Russian) [Гайский В.Н. Статистические исследования сейсмического режима. М.: Наука, 1970. 123 с.].

Gardner J.K., Knopoff L., 1974. Is the sequence of earthquakes in Southern California, with aftershocks removed, Poissonian? Bulletin of the Seismological Society of America 64 (5), 1363-1367.

Golenetskii S.I., 1961. Determinations of the crust thickness from observations of waves reflected from the crust base and source depths of aftershocks of the Middle Baikal earthquakes of August 29, 1959. Geologiya i Geofizika 2, 111-116 (in Russian) [Голенецкий С.И. Определение мощности земной коры по наблюдениям волн, отраженных от ее подошвы, и глубины залегания очагов афтершоков Среднебайкальского землетрясения 29 августа 1959 г. // Геология и геофизика. 1961. № 2. С. 111-116].

Golenetskii S.I., 1977. Seismicity of the Baikal region: history of its studying and some results. In: Gorshkov G.P. (Ed.), Seismicity and seismogeology of the East Siberia. Nauka, Moscow, p. 3-42 (in Russian) [Голенецкий С.И. Сейсмичность Прибайкалья - история ее изучения и некоторые итоги // Сейсмичность и сейсмогеология Восточной Сибири / Под ред. Г.П. Горшкова. М.: Наука, 1977. С. 3-42].

Golenetskii S.I., 2001. The review of seismicity: Pribaikalie and Transbaikalie. In: Earthquakes in the Northern Eurasia in 1995. GS RAS, Moscow, p. 68-75 (in Russian) [Голенецкий С.И. Обзор сейсмичности: Прибайкалье и Забайкалье // Землетрясения Северной Евразии в 1995 году. М.: ГС РАН, 2001. С. 68-75].

Golenetskii S.I., Ruzhich V.V., Drennova G.F., 1997. The earthquake of 12 (13) May 1991 in Babushkin settlement and seismicity of the Southern Baikal. In: Earthquakes in the USSR in 1991. UIPE RAS, Moscow, p. 47-52 (in Russian) [Голенецкий С.И., Ружич В.В., Дреннова Г.Ф. Землетрясение 12 (13) мая 1991 г. в районе пос. Бабушкин и сейсмичность Южного Байкала // Землетрясения в СССР в 1991 г. М.: ОИФЗ РАН, 1997. С. 47-52].

Hutton K., Woessner J., Hauksson E., 2010. Earthquake monitoring in Southern California for seventy seven years (19322008). Bulletin of the Seismological Society of America 100 (2), 423-446. http://dx.doi.org/10.1785/0120090130.

Khromovskikh V.S., Nikolaev V.V., Dem'yanovich M.G., Chipizubov A.V., Semenov R.M., Serebrennikov S.P., Arzhannikov S.G., Smekalin O.P., Del'yansky E.A., 1996. The new seismic zoning map of the Northern Eurasia. In: Geophysical studies of East Siberia at the turn of the 21st century. Nauka, Novosibirsk, p. 94-99 (in Russian) [Хромовских В.С., Николаев В.В., Демьянович М.Г., Чипизубов А.В., Семёнов Р.М., Серебренников С.П., Аржанников С.Г., Смекалин О.П., Дельянский Е.А. Новая карта сейсмического районирования территории Северной Евразии // Геофизизические исследования в Восточной Сибири на рубеже XXI века. Новосибирск: Наука, 1996. С. 94-99].

Kochetkov V.M., Borovik N.S., Leontieva L.R., Gileva N.A., 1977. The detailed analysis of the seismic field of the Pribaikalie. In: Seismicity and seismology of East Siberia. Nauka, Moscow, p. 62-73 (in Russian) [Кочетков В.М., Боровик Н.С., Леонтьева Л.Р., Гилева Н.А. Детальный анализ сейсмического поля Прибайкалья // Сейсмичность и сейсмогеология Восточной Сибири. М.: Наука, 1977. С. 62-73].

Kochetkov V.M., Borovik N.S., Misharina L.A., Solonenko A.V., Anikanova G.V., Solonenko N.V., Melnikova V.I., Gileva N.A., 1987. Angarakan swarm of earthquakes in the Baikal Rift Zone. Nauka, Novosibirsk, 189 p. (in Russian) [Koчemков В.М., Боровик Н.С., Мишарина Л.А., Солоненко А.В., Аниканова Г.В., Солоненко Н.В., Мельникова В.И., Гилева Н.А. Ангараканский рой землетрясений в Байкальской рифтовой зоне / Отв. ред. О.В. Павлов. Новосибирск: Наука. СО, 1987. 189 с.].

Kochetkov V.M., Khilko S.D., Nikolaev V.V., Koz'min B.M., 1975. The Tas-Yuryakhskoye earthquake of 18 January 1967. In: Seismotectonics, deep structure and seismicity of the North-Eastern part of the Baikal rift zone. Novosibirsk, Nauka, p. 71-94 (in Russian) [Кочетков В.М., Хилько С.Д., Николаев В.В., Козьмин Б.М. Тас-Юряхское землетрясение 18 января 1967 г. // Сейсмотектоника, глубинное строение и сейсмичность северо-востока Байкальской рифтовой зоны. Новосибирск: Наука, 1975. С. 71-94].

Kondorskaya N., Shebalin N. (Eds.), 1982. New Catalogue of Strong Earthquakes in the USSR from Ancient Times through 1977. World Data Centre A, U.S. Department of Commerce, Washington DC, 602 p.

Kozmin B.M., 2003. Yakutia (Review of Seismicity). In: Earthquakes in the Northern Eurasia in 1997. GS RAS, Obninsk, p. 151-155 (in Russian) [Козьмин Б.М. Якутия (Обзор сейсмичности) // Землетрясения Северной Евразии в 1997 г. Обнинск: ГС РАН, 2003. С. 151-155].

Melnikova V.I., Gileva N.A., Arefiev S.S., Bykova V.V., Masalskii O.K., 2012. The 2008 Kultuk earthquake with $M_{\mathrm{w}}=6.3$ in the south of Baikal: Spatial-temporal analysis of seismic activation. Izvestiya, Physics of the Solid Earth 48 (7-8), 594614. http://dx.doi.org/10.1134/S1069351312060031.

Mel'nikova V.I., Gileva N.A., Radziminovich N.A., Masal'skii O.K., Chechel'nitskii V.V., 2010. Seismicity of the Baikal rift zone for the digital recording period of earthquake observation (2001-2006). Seismic Instruments 46 (2), 193-206. http:// dx.doi.org/10.3103/S0747923910020076.

Mirzoev K.M., Rakhmatullin M.Kh, Gatiyatullin R.N., 2000. Tatarstan (from ancient times to 1994). In: Earthquakes in the 
Northern Eurasia in 1994. UIPE GS RAS, Moscow, p. 44-56 (in Russian) [Мирзоев К.М., Рахматуллин М.Х., Гатиятуллин Р.Н. Татарстан (с древнейших времен по 1994 год) // Землетрясения Северной Евразии в 1994 году. М.: ОИФЗ ГС РАН, 2000. С. 44-56].

Misharina L.A., 1961. Aftershocks of the Middle Baikal Earthquake of August 29, 1959. Geologiya i Geofizika 2, 105-110 (in Russian) [Мишарина Л.А. Афтершоки Среднебайкальского землетрясения 29 августа 1959 г. // Геология и геофизика. 1961. № 2. С. 105-110].

Mogi K., 1963. Some discussions on aftershocks, foreshocks and earthquake swarms - the fracture of a semi-infinite body caused by an inner stress origin and its relation to the earthquake phenomena, 3. Bulletin of the Earthquake Research Institute, Tokyo University 41, 615-658.

Molchan G.M., Dmitrieva O.E., 1991. Identification of aftershocks: a review and new approaches. Vychislitel'naya Seismologiya 24, 19-50 (in Russian) [Молчан Г.М., Дмитриева О.Е. Идентификация афтершоков: обзор и новые подходы // Вычислительная сейсмология. 1991. Вып. 24. С. 19-50].

Molchan G.M., Dmitrieva O., 1992. Aftershock identification: methods and new approaches. Geophysical Journal International 109 (3), 501-516. http://dx.doi.org/10.1111/j.1365-246X.1992.tb00113.x.

Ochkovskaya M.G., Radziminovich N.A., 2011. Preliminary results of the analysis of aftershock sequences of the Baikal rift zone. Izvestiya Irkutskogo Gosudarstvennogo Universiteta. Seriya Nauki o Zemle 4 (1), 164-172 (in Russian) [Очковская М.Г., Радзиминович Н.А. Предварительные результаты анализа афтершоковых последовательностей Байкальской рифтовой зоны // Известия Иркутского государственного университета. Серия «Науки о Земле». 2011. T. 4. № 1. С. 164-172].

Potanina M.G., Smirnov V.B., Bernar P., 2011. Patterns of seismic swarm activity in the Corinth Rift in 2000-2005. Izvestiya, Physics of the Solid Earth 47 (7), 610-622. http://dx.doi.org/10.1134/S106935131106005X.

Prozorov A.G., 1986. The dynamic algorithm for determination of aftershocks for the world earthquake catalogue. Mathematical methods in seismology and geodynamics. Vychislitel'naya Seismologiya 19, 58-62 (in Russian) [Прозоров А.Г. Динамический алгоритм выделения афтершоков для мирового каталога землетрясений. Математические методы в сейсмологии и геодинамике // Вычислительная сейсмология. 1986. Вып. 19. С. 58-62].

Pshennikov K.V., 1962. Some features of repeated shocks of earthquakes in the Pribaikalie and Mongolia. Geologiya $i$ Geofizika 4, 26-30 (in Russian) [Пшенников К.В. Некоторые особенности повторных толчков землетрясений Прибайкалья и Монголии // Геология и геофизика. 1962. № 4. С. 26-30].

Pshennikov K.V., 1965. The Mechanism of Occurrence of Aftershocks and Non-elastic Properties of the Earth's Crust. Nauka, Moscow, 86 p. (in Russian) [Пшенников К.В. Механизм возникновения афтершоков и неупругие свойства земной коры. М.: Наука, 1965. 86 с.].

Radziminovich N.A., 2010. Focal depths of earthquakes in the Baikal region: a review. Izvestiya, Physics of the Solid Earth 46 (3), 216-229. http://dx.doi.org/10.1134/S1069351310030043.

Radziminovich N., Gileva N.A., Melnikova V.I., Ochkovskaya M.G., 2013. Seismicity of the Baikal rift system from regional network observations. Journal of Asian Earth Sciences 62, 146-161. http://dx.doi.org/10.1016/j.jseaes.2012.10.029.

Radziminovich N.A., Imaeva L.P., Mel'nikova V.I., Imaev V.S., 2006. Seismotectonic position of the Oldongsinsky swarm and aftershock sequences of 2005 (the north-eastern flank of BRZ). In: Proceedings of the meeting on the geodynamic evolution of the lithosphere in the Central Asian mobile belt (from the ocean towards the continent). IEC SB RAS, Irkutsk, Issue 4, Vol. 2, p. 87-90 (in Russian) [Радзиминович Н.А., Имаева Л.П., Мельникова В.И., Имаев В.С. Сейсмотектоническая позиция Олдонгсинского роя и афтершоковой последовательности 2005 г. (северо-восточный фланг БР3) // Геодинамическая эволюция литосферы Центрально-Азиатского подвижного пояса (от океана к континенту): Материалы совещания. Иркутск: ИЗК СО РАН, 2006. Вып. 4. Т. 2. С. 87-90].

Radziminovich N.A., Kustova M.G., Gileva N.A., 2008. Changes in seismicity before large earthquakes of the Baikal rift zone // Abstracts of the 7th General Assembly of Asian Seismological Commission and the 2008 Fall meeting of Seismological Society of Japan. Tsukuba, Japan, 24-27 November, 2008. 141 p.

Radziminovich N.A., Melnikova V.I., Koz'min B.M., Tatomir N.V., 2004. The Oldongsinsky swarm of earthquakes of 19972002 at the north-eastern flank of the Baikal rift zone. In: Geodynamics and geological changes of the environment of the Northern regions: Proceedings of the All-Russian conference with International Participation (Arkhangelsk, 13-18 September 2004). Arkhangelsk, Vol. 2, p. 193-196 (in Russian) [Радзиминович Н.А., Мельникова В.И., Козьмин Б.М., Татомир Н.В. Олдонгсинский рой землетрясений 1997-2002 гг. на северо-восточном фланге Байкальской рифтовой зоны // Геодинамика и геологические изменения в окружающей среде северных регионов: Материалы Всероссийской конференции с международным участием (Архангельск, 13-18 сентября 2004 г.). Архангельск, 2004. T. 2. C. 193-196].

Reasenberg P., 1985. Second-order moment of central California seismicity, 1969-82. Journal of Geophysical Research: Solid Earth 90 (B7), 5479-5495. http://dx.doi.org/10.1029/JB090iB07p05479.

Romashkova L.L., Kossobokov V.G., 2001. Seismicity dynamics prior to and after the largest earthquakes worldwide, 1985 2000. Vychislitel'naya Seismologiya 32, 162-189 (in Russian) [Ромашкова Л.Л., Кособоков В.Г. Динамика сейсмической активности до и после сильнейших землетрясений мира, 1985-2000 // Вычислительная сейсмология. Вып. 32. 162-189].

Saltykov V.A., Kravchenko N.M., 2010. Parameters of Kamchatka seismicity in 2008. Geodynamics \& Tectonophysics 1 (2), 
N.A. Radziminovich, M.G. Ochkovskaya: Identification of earthquake aftershock and swarm sequences...

186-196. http://dx.doi.org/10.5800/GT-2010-1-2-0014.

Sankov V.A., Dneprovskii Yu.I., Kovalenko S.N., Bornyakov S.A., Gileva N.A., Gorbunova N.G., 1991. Faults and Seismicity of the Severomuiskii Geodynamic Research Area. Nauka, Novosibirsk, 111 p. (in Russian) [Саньков В.А., Днепровский Ю.И., Коваленко С.Н., Борняков С.А., Гилева Н.А., Горбунова Н.Г. Разломы и сейсмичность Северо-Муйского геодинамического полигона. Новосибирск: Наука, 1991. 111 с.].

Smirnov B.V., Gabsatarova I.P., 2000. The representativity of the earthquake catalog of the North Caucasus: estimated data and statistical evaluations. Vestnik OGGGGN RAN 4 (14). Available from: http://www.scgis.ru/russian/cp1251/ h_dgggms/4-2000/smirnov.htm (in Russian) [Смирнов В.Б., Габсатарова И.П. Представительность каталога землетрясений Северного Кавказа: расчетные данные и статистические оценки // Вестник ОГГГГН РАН. 2000. Т. 4. № 14. Available from: http://www.scgis.ru/russian/cp1251/h_dgggms/4-2000/smirnov.htm].

Solonenko N.V., Solonenko A.V., 1987. Aftershock Sequences and Earthquake Swarms in the Baikal Rift Zone. Nauka, Novosibirsk, 91 p. (in Russian) [Солоненко Н.В., Солоненко А.В. Афтершоковые последовательности и рои землетрясений в Байкальской рифтовой зоне. Новосибирск: Наука, 1987. 91 с.].

Solonenko V.P., Treskov A.A., 1960. The Middle Baikal earthquake of August 29, 1959. Irkutsk Publishing House, Irkutsk, 36 p. (in Russian) [Солоненко В.П., Тресков А.А. Среднебайкальское землетрясение 29 августа 1959 года. Иркутск: Иркутское книжное издательство, 1960. 36 с.].

Waite G.P., 1999. Seismicity of the Yellowstone Plateau: space-time patterns and stresses from focal mechanism inversion: M.S. thesis. University of Utah, Salt Lake City.

Zhuang J., Ogata Y., Vere-Jones D., 2002. Stochastic declustering of space-time earthquake occurrences. Journal of the American Statistical Association 97 (458), 369-380.

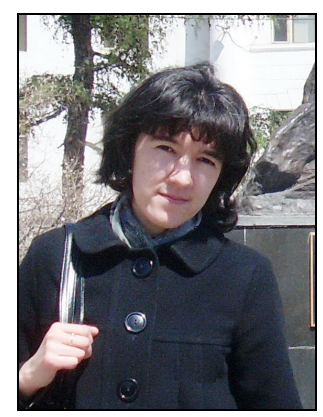

Радзиминович Наталья Анатольевна, канд. геол.-мин. наук, с.н.с.

Институт земной коры СО РАН

664033, Иркутск, ул. Лермонтова, 128, Россия

Тел.: 89642160520; $\$ e-mail: nradzim@crust.irk.ru

Radziminovich, Natalia A., Candidate of Geology and Mineralogy, Senior Researcher Institute of the Earth's Crust, Siberian Branch of RAS

128 Lermontov street, Irkutsk 664033, Russia

Tel.: 89642160520; $\$ e-mail: nradzim@crust.irk.ru

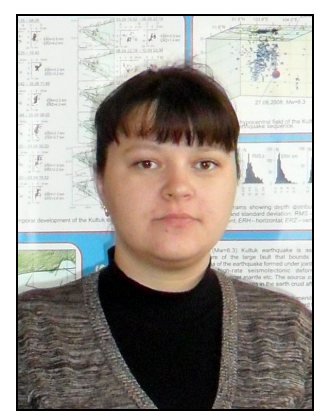

Очковская Марина Георгиевна, инженер

Байкальский филиал Геофизической службы СО РАН

664033, Иркутск, ул. Лермонтова, 128

Тел.: 89641016191; e-mail: kustova@crust.irk.ru

Ochkovskaya, Marina G., Engineer

Baikal Division of Geophysical Survey, Siberian Branch of RAS

128 Lermontov street, Irkutsk 664033, Russia

Tel.: 89641016191; e-mail: kustova@crust.irk.ru 